\title{
Technology as an Educational Equalizer for EFL Learning in Rural China? Evidence from the Impact of Technology-Assisted Practices on Teacher-Student Interaction in Primary Classrooms
}

\author{
GUOFANG LI \\ University of British Columbia \\ YOUNGEUN JEE \\ University of British Columbia \\ ZHUO SUN \\ University of British Columbia
}

\begin{abstract}
Based on a conversational analysis (CA) of eight videoed EFL lessons from technologyenhanced primary classrooms in a rural suburb of a major city in China, this study examines the nature of technology-assisted practices and their influence on teacher-student interaction in the target language. The analysis revealed that the technology-assisted practices mainly served as an alternative presentation tool to meet a range of traditional pedagogical goals and facilitated minimal spontaneous language use among the students. The findings call for research to explore better pedagogical use of technology to promote students' active language production to truly achieve educational equalization for rural students.
\end{abstract}

\section{Keywords}

educational equalizer, teacher-student interaction, initiation-response feedback (IRF), conversational analysis (CA), English as foreign language, primary schools, rural China

\section{Introduction}

Information and Communication Technology (ICT) has been used for the binary purposes of educational modernization and equalization in many countries including China. For example, in response to the urgent need for educational modernization and internationalization, multimedia and computer technologies have been increasingly implemented in K-12 English as a Foreign Language (EFL) classrooms in China since the late 1990s to help create constructive, supportive, and rich learning environments (G. Li, 2015; Song et al., 2005; C. R. Yang, 2007). The National Curriculum for Nine-Year Compulsory Education for English (Chinese Ministry of Education, 2001) requires that K12 English teachers (in both rural and urban areas) create a near-natural language environment with the aid of technological teaching tools. To facilitate this policy, the Ministry of Education, as well as local educational agencies, has made considerable investments in technology resources-including both software and hardware in K-12 schools - to transform the traditional model of foreign language education in the Chinese context (Li \& Ni, 2012; J. Xu, 2010).

Despite these efforts, there still exists a great digital divide in technology use and 
access in K-12 classrooms between rural and urban schools. While over 85\% of urban schools have access to computers and the Internet, less than $75 \%$ of rural schools have that privilege (Chinese Ministry of Education, 2016; Mo, 2015). Additionally, while close to $80 \%$ of students in urban areas have access to computers and the Internet at home, only one in ten rural students can afford a home computer and less than 3\% have any access to the Internet at home (Rural Education Action Program, or REAP, 2018). Moreover, the divide is greater between school and home access to hardware and software. As a REAP (2018) brief describes: "Few rural schools have computers, and when they do, the machines are often archaic or broken. Moreover, only about one third of the computers are equipped with any type of learning software-none of which are aligned with the national curriculum” (p. 3).

Equally severe is the lack of professional support for rural teachers. Despite being the group who need professional development the most, rural teachers receive the least training opportunities to keep up with the latest pedagogical theories and multimedia techniques (Lin, 2004; Marton, 2006).

Accompanying this great digital divide are the widely reported growing achievement gaps (Fan \& Cheng, 2015; Ke, 2016; REAP, 2018; Zhang \& Zhao, 2014. China's rural children are one of the "poorest performing groups of students in the country" (REAP, 2018, p. 2). For example, results from one standardized math test show that rural Shaanxi students are 11.1 points behind their Beijing public school peers (Mo et al., 2013; Mo et al., 2014). A few large-scale studies have provided supporting evidence of the urbanrural achievement gap in EFL education in China. Ke's (2016) statistical analysis of students' (Grade 9 equivalent) high-school entrance exam results (including English) in recent years yielded evidence of a declining trend in the likelihood of rural students achieving high scores in this high-stakes provincial test, since the implementation of China's new curriculum in 2006. It is worth noting that in 2010, rural students' chance of achieving high marks in the subject of English—along with Chinese, Math, and Political Science-was only 50-60\% of that of urban students. The rural-urban achievement disparity in English is further substantiated in Fan and Cheng's (2015) empirical analysis of students' College Entrance Exam results from Chongqing, a major municipality in western China. By cross-comparing English test results of urban and rural students in corresponding percentile ranges, the study concludes that rural students were remarkably underachieved in the English exam, as both high- and low-ranked rural test-takers performed below the urban students and the city average. Not surprisingly, rural students are also reported to suffer from high levels of study/test anxiety, which has been found to negatively impact their English test scores (J. Li, 2007). Due to these disparities, the Chinese Ministry of Education (2012), in its "Plan for ICT in Education 2011-2020," mandates that special focus should be put on ICT use and infrastructure building in rural, poor, and ethnic areas, in order to narrow the digital divide and education gaps among regions and schools.

Existing limited research on the impact of ICT on rural Chinese children's educational improvement, however, is mixed. While some large-scale experiments of using ICT to improve rural students' Chinese and math scores have been reported to be effective in promoting positive learning outcomes (Mo et al., 2013; Mo, et al., 2014), other studies, such as those by Lai et al. (2016), are not as positive. Even fewer studies have explored the impact of ICT on rural children's EFL learning, largely due to the existing digital divide 
between rural and urban schools and the fact that major educational reform efforts have concentrated on strengthening English language teaching in elite schools in urban areas ever since English was re-introduced into basic education curricula in the late 1970s (Hu, 2005; Rong \& Shi, 2001).

Existing studies from developed urban schools reveal that many Chinese EFL teachers embrace the possibilities of technology, and hold the belief that technology can help them connect curriculum to authentic language tasks and result in more productive learning outcomes (Su \& Jing, 2007; J. Xu, 2010; Y. Zhao, 2003). With the potential benefits of providing high quality linguistic and cultural materials, communicative opportunities, individualized feedback, and increased student motivation, technologyassisted pedagogical practices in Chinese EFL classroom has been shown to enhance the teaching of different sets of English language skills, including English writing skills (Leng, 2005), vocabulary (Zhang, 2009), and reading skills (Gao, 2009; Li \& Ni, 2008, 2013).

Despite these benefits, researchers on technology use in EFL classrooms are concerned that teachers' reliance on technology may decrease interaction between teachers and students, thereby reducing students' opportunities to develop oral language skills during lessons supported by technology use (e.g., Li \& Ni, 2012; C. H. Xu, 2006; J. Xu, 2010). Indeed, research has identified a significant mismatch between Chinese EFL teachers' beliefs about technology and their pedagogical practices using technology in daily classroom teaching ( $\mathrm{Li} \& \mathrm{Ni}$, 2011a; L. Li \& Walsh, 2010; J. Xu, 2010; Zhong \& Shen, 2002). In particular, many Chinese EFL teachers still use technology mainly as teachers' lesson delivery tools (i.e., as replacements for chalk boards) rather than studentcentered learning tools within a communicative and interactive language-learning environment (Fang \& Warschauer, 2004; Li \& Ni, 2012;). Therefore, without teachers' proper uptake of the essence of educational technology, there may be little difference between the teacher-student interaction in technology-enhanced EFL classrooms and the teacher-student interaction in traditional classrooms without technology in China.

Current research on teacher-student interaction in EFL classrooms in China and other countries has mostly centered on classrooms without technology in secondary or post-secondary settings (e.g., Ahangari \& Amirzadeh, 2011; Faruji, 2011; Lei, 2009; Liu \& Le, 2012; Panova, \& Lyster, 2002; Qashoa, 2013; Walsh, 2002). Few (e.g., Kim, 2005; J. Lee, 2007; B. Zhao, 2009) have aimed to understand teacher-student interaction in primary EFL classrooms without the presence of technology. The scarcity of research on teacher-student interaction with young learners, who present distinctively different cognitive and behavioural patterns and needs than their older peers, has resulted in what Jung (2005) calls an "unfortunate top-down tendency," whereby technology-enhanced language teaching in higher education sectors percolates down to younger learners without differentiated pedagogical modifications. To better serve their learning needs, more attention needs to be devoted to the learners at lower grade levels who are most likely to benefit from the affordance of authentic language input in technology-enhanced EFL settings. Therefore, while the inclusion of multimedia technology enables diverse classroom activities in EFL classrooms, its influences on classroom interactions, especially in the context of primary EFL classrooms in rural schools, remains under-examined.

Most of the extant studies on Chinese EFL teachers' technology-assisted pedagogical beliefs and practices have been conducted without proper reference to the cross-regional disparity in the distribution of financial and educational resources, 
especially considering the reality of rural schools in China (Qian \& Smyth, 2008). Moreover, the new, mandated national curriculum has been reported to contain standards and pacing that are unreasonably high and too fast, respectively, for poor-performing rural students (Hu, 2005; Ke, 2016). Without sufficient access to technological and professional support, primary schools in rural areas are left struggling to complete a state mandated curriculum that is already overloaded for low-achieving rural students (D. Wang, 2011).

To address the above-mentioned gaps in the literature, this study aims to understand the nature of technology-enhanced EFL instruction in suburban/rural primary schools in China. We assumed a discourse perspective to examine the features and patterns of teacherstudent interaction within these classrooms. The study was guided by the following research questions:

1) How was multimedia technology used in primary EFL classrooms in suburban/rural China?

2) How did teachers' technology use influence teacher-student interaction in these classrooms? Specifically, what is the nature of teacher talk, student response, and teacher feedback in these technology-mediated classrooms?

\section{Understanding Teacher-Student Interaction in EFL Classrooms: Initiation-Response- Feedback (IRF)}

Classroom interaction encompasses verbal and non-verbal interaction between teachers and students, and among students (Tsui, 2001). The most familiar pattern of teacher-student verbal interaction is a three turn-taking sequence: Initiation-responsefeedback (Sinclair \& Coulthard, 1975) or initiation-response-evaluation (Mehan, 1979). In this pattern, classroom interaction starts with a teacher-led initiation-usually in the form of guidelines or directions for a lesson-which is often followed by a student response. The sequence of interaction concludes with the teacher providing feedback on or evaluating the student response. Studies of classroom interaction in L2 classrooms have focused on all three steps of the teacher-student interaction sequence, specifically examining teachers' language use, especially teacher questions (Faruji, 2011; Y. Lee, 2008; Qashoa, 2013); learner responses (Walsh, 2002); and teacher feedback and turn allocation behaviors (B. Zhao, 2009).

Research on EFL teacher initiation question types indicates that EFL teachers frequently adhere to a prototypical question-answer format, using open or closed display questions (questions with answers known by the teacher) more often than open or closed referential questions (the answers to which the teacher does not know) (Y. Lee, 2008; Long \& Sato, 1983; Thornbury, 1996; Tsui, 2001; Walsh, 2002). Although both types of questions can serve as a comprehension check or as a means of clarification or confirmation, several studies have found that teachers' use of display questions is less effective than that of referential questions in promoting student opportunities to use L2, despite the excessive use of display questions in teacher-centered EFL classrooms (Farahian \& Rezaee, 2012; Qashoa, 2013; Thornbury, 1996). In a study of EFL teachers' question types and syntactic structures in United Arab Emirates secondary school classrooms, Qashoa (2013) found that among 105 questions asked by three teachers, 65 (62\% of the total questions) were display questions while only 40 (38\%) were referential questions. On average, referential questions led to longer student responses that included 
opinions or interpretations of specific topics. However, teachers' abilities to pose more referential questions are often affected by their own language proficiency and experience (Farahian \& Rezaee, 2012).

Existing literature on student output in EFL classrooms has revealed that the quantity and quality of EFL students' responses are mostly restricted due to excessive teacher talk time and the teacher's control over the content and procedure of classroom interaction (Cheng, 2009; Walsh, 2002). In their study of four college EFL classrooms in China, Liu and Le (2012) found that the average amount of teacher talk time (68.89\%) surpassed student talk time (21.66\%) and other activities time (6.67\%) in a 45 -minutes class. Based on the audio recordings of eight experienced EFL teachers' lessons (two 30minute lessons videos from each teacher), Walsh (2002) found that some features of teachers' language, such as teacher-fronted tasks, teachers "filling the gaps" after turn completion, teacher echo, and teacher interruptions, discourage students' involvement and hinder teacher-student interaction. Teachers' echoing or repeating of students' utterances, for example, seemed to facilitate the flow of discourse, but it was often done out of habit, without real pedagogical functions.

In addition to teachers' initiation and students' responses, studies of EFL classrooms reveal that teachers employ various strategies, including positive feedback (such as compliments), corrective feedback, and non-evaluative feedback (such as echoing, back-channeling, and directives) to respond to students, especially when students produce errors in their utterances (e.g., Long \& Sato, 1983; Walsh; 2002; Y. Yang, 2008). Among these feedback types, corrective feedback, the umbrella term that covers negative feedback in naturalistic and instructional settings, is most often researched. Corrective feedback includes the implicit provision of target language forms (i.e., recast), techniques for selfcorrection (i.e., clarification request, metalinguistic feedback, elicitation, and repetition), and explicit error correction techniques (Lyster \& Ranta, 1997; Panova \& Lyster, 2002; Sheen, 2004). Findings on corrective feedback in EFL classrooms (Ahangari \& Amirzadeh, 2011; Kennedy, 2010; Panova \& Lyster, 2002; Sheen, 2004) indicate that recast (when the teacher implicitly reformulates the student's error, or provides the correction) is the predominant technique that teachers employ, even though it leads to the lowest rate of uptake of the target language. In comparison, techniques that encourage student selfresponses, such as clarification requests, metalinguistic feedback (when the teacher poses questions related to the formation of a student's utterances), elicitation (when the teacher directly elicits the correct form from the student by asking questions, pausing, or asking for correction), and repetition, lead to more successful student-generated repair (J. Lee, 2007). Among these techniques, elicitation is the most successful type of corrective feedback that leads to learners' repair. Finally, research has also found that teachers tend to use recast more frequently with learners of lower L2 proficiency, often incorporating more self-correction techniques as learners become more proficient (Ahangari \& Amirzadeh, 2011).

In summary, findings from these studies show that in many EFL contexts, teachers still dominate the classroom, and that teachers' dominance affects the kind of feedback they provide to students as well as students' responses. These findings on teacher-student interaction are based exclusively on classrooms without technology support. Such is also the case of classroom interaction research in the EFL context in China (e.g., Liu \& Le, 2012; X. L. Qian, Tian \& Z. Wang, 2009; B. Zhao, 2009); thus, whether or how the 
presence of technology affects teacher-student interaction in Chinese EFL classrooms remains under-examined. In this present study, we focused on classroom interaction between primary EFL teachers and students in China and examined how technology integration in classes shapes classroom discourse.

\section{Research Method}

\section{Data Collection}

The data used for this study were a part of a large-scale research project on technology-enhanced EFL instruction that included 37 EFL (Grades 4 and 5) teachers from 26 primary schools in a suburban/rural school district outside a major city in China. Based on a survey about information technology integration in primary and secondary schools in the city, there was an unequal distribution of the technology resources across different school districts in the capital area. In addition, there was a scarcity of quality courseware for teachers to meet their instructional needs in the classrooms, and many teachers had to make courseware themselves to assist with their classroom teaching. Therefore, the primary schools included in this study were among those with less technology access and support.

Each of the participating teachers' classroom teaching was recorded 1-2 times over two consecutive years (2009 and 2010), resulting in a total of 114 class videos, each lasting between 35 to 45 minutes in length. For the purpose of this paper, nine videos on the same lesson (Unit 3: Visit Grandpa’s Farm) recorded in 2009 were selected on a random basis for detailed analysis. While the specific objectives of each teacher's lesson varied, the common goals of the lesson included a) listen, recognize, and understand core words (such as the name of an animal, its color, diet, habitat, etc.); b) read and understand the dialogue in the textbook; c) memorize the simple sentences introduced in this lesson, and use them to create dialogues to introduce an animal; and d) cultivate a love for animals. After a preliminary examination of the videos, one was excluded as an outlier due to the teacher's lack of technological practices (the teacher conducted only one technology-assisted activity, far below the average of 4.57 activities of the other seven videos).

\section{Data Analysis}

For the analysis of the transcribed data, we adopted the method of conversational analysis (CA) that is often used to study the social organization of "talk-in-interaction," inspecting in detail the tape recordings and transcriptions made from such recordings (Markee, 2000; Sacks, 1992; Ten Have, 2007). As a discourse analysis method, CA is fundamentally "concerned with the relationship between language and the contexts of its use” (McCarthy, 1991, p. 10). In this study, said relationship was examined through the lens of social interaction, with specific attention to the turn-by-turn sequence of talk between teachers and students in naturally occurring technology-mediated classrooms.

Teachers' patterns of technology use were analyzed through their time allocation for technology-enhanced instruction and the types of technology use within or across class activities. To better understand the classroom discourses uttered by teachers and students when these teaching materials were introduced, the eight videos were transcribed verbatim. The transcripts were then imported to NVivo 11.4.0 for further coding and analysis.

We drew from Sinclair and Coulthard's (1975) Exchange-Move-Act discourse 
structure as our primary coding guide. In this model, an exchange refers to a complete three turn-taking sequence: Initiation-response-feedback. Within an exchange, each turn or talk that serves either as an initiation, response, or feedback function is called a move. Each move is composed of different speech acts that serve different communication purposes, such as eliciting responses using questions, checking for readiness or any problems, prompting or demanding a response (e.g., go on, come on, have a guess), giving a directive or command to action, acknowledging a response (e.g., yes, OK, wow), or marking the end or beginning of a conversation (e.g., the use of 'well,' 'OK,' 'now,' 'good,' 'right,' or 'alright').

Following the Exchange-Move-Act structure, we first segmented the transcripts into a series of exchanges. Each exchange was further analyzed according to the three turntaking moves - namely, teacher initiation, student response, and teacher feedback. Within each move, functions for utterances were labeled as speech acts. Below is an example of an Exchange-Move-Act analysis:

Exchange (TA: Teacher A; Ss: All students; S43: The $43^{\text {rd }}$ student who responded to teacher's elicitation)

1. TA (Initiation move): Who can have a try? [Teacher act: check] Mingming's favorite animals? [Teacher act: Elicitation]

2. S43 (Response move): Mingming's favorite animals are goose. [Student act: positive response]

3. TA (Feedback move): Geese. [Teacher act: Recast]

For teacher initiation moves, we first coded the speech acts following Sinclair and Coulthard's (1992) taxonomy, which contains 31 categories (see Appendix 1). Teachers' elicitation acts characterized by questions and statements were the most frequent occurrences. Teachers' question types that intended to elicit a linguistic response were analyzed by following Long \& Sato's (1983) classification of referential and display questions. Commands or statements within the elicitation act were labeled as nonquestions. In addition, based on our data, we included "model reading" and "directive to action" (usually realized by imperatives functioning as requests to non-verbal responses) to be the speech acts in teachers' initiation moves (Sinclair \& Coulthard, 1992). Besides these categories, checking for readiness or any problems and prompting or demanding a response were frequent acts within the initiation move.

Table 1 below provides examples of common speech acts in teachers' initiation moves. 
Table 1

Examples of Teachers’ Common Speech Acts in Initiation Moves

\begin{tabular}{lll}
$\begin{array}{l}\text { Types of speech } \\
\text { acts in initiation } \\
\text { move }\end{array}$ & Example \\
\hline Elicitation & Referential questions & $\begin{array}{l}\text { TB: Have you ever seen this kind } \\
\text { of bird? }\end{array}$ \\
\cline { 2 - 3 } & Display questions & $\begin{array}{l}\text { TA: So, what is Mingming's } \\
\text { favorite animal? }\end{array}$ \\
\cline { 2 - 3 } & Non-questions & $\begin{array}{l}\text { TC: } \text { Now, let's go on. Deer. } \\
\text { Ss: Deer, panda, sheep. }\end{array}$ \\
\hline Model reading & $\begin{array}{l}\text { TA: Read after me: Deer live in } \\
\text { the wild. }\end{array}$ \\
\hline Check & TF: Who can read? \\
\hline Directive to & TC: Read after me. \\
Action & & \\
\hline
\end{tabular}

For the analysis of students' response acts, we first applied the categorization of Restricted/Expanded (Arizavi, Kalhor, Namdari, \& Mousavi, 2015; Tsui, 1985; Wu, 1993) responses to capture the quantitative nature of student talk. According to Wu (1993) and Tsui (1985), a Restricted response is often realized by a single word or a simple sentence. Expanded response, in contrast, is defined as two or more coherently linked sentences that express, for instance, judgment or evaluation. Our second round of coding used a set of response acts specific to EFL classroom settings. Developed by Rashidi and Rafieerad (2010), this set of response acts builds on Tsui's $(1985,1994)$ taxonomy of discourse acts to include temporation and repair acts. Temporization acts describe whether students' responses "fulfil the interactional expectation" (positive responses) or "challenge the presuppositions of the requestive” (negative responses) (Tsui, 1994, p. 59). Repair acts include self-repair (student corrects the mistake) and peer-repair (other students initiate the correction).

Table 2

Examples of Students’ Common Speech Acts in Response Moves.

Example

Restricted TG: This is a?

S2: Dog.

Expanded TD: If you are a tiger, how to introduce yourself?

S55: Hello. I am a tiger. Um, I roar and roar. I am yellow. I eat small animals. I can run and jump. I live on the grassland. 


\begin{tabular}{ll}
\hline Positive Response & TC: Read after me. Dove. \\
& Ss: Dove. \\
\hline Negative Response & TB: (Moving his arms) Follow me. \\
& S12: Follow me. \\
& TB: 不是重复说 (I’m not asking you to repeat) . \\
\hline Temporization & TH: Now, who can tell me what other animals do you know? \\
& S16: 我不知道了 (I don't know more). \\
\hline Self-repair & Ss: In the grass. \\
& TD: In or on? \\
& Ss: On the grass. \\
\hline Peer-repair & Ss: Geese. \\
& TG: This is a? \\
& Ss: Goose.
\end{tabular}

We used three basic categories of codes to help examine speech acts within teachers' feedback moves: Acceptance, Corrective Feedback, and Directive to Action. Acceptance of a student response includes positive evaluation, echo, and back-channel (Verplaetse, 1995, 2000). Teachers' Corrective Feedback acts were coded according to Lyster and Ranta's (1997) taxonomy, which includes recast, clarification requests, explicit correction, repetition, elicitation and metalinguistic clues. And finally, Directive to Action acts, as are explained under initiation moves, also appeared in teachers' feedback moves (see examples below in Table 3).

Table 3

Examples of Teachers' Common Speech Acts in Feedback Moves

\begin{tabular}{lll}
$\begin{array}{l}\text { Types of Teachers' } \\
\text { Feedback }\end{array}$ & Example \\
\hline Acceptance & Positive evaluation & TB: Ok, very good. \\
\cline { 2 - 3 } & Echo & Ss: Lion. \\
& TD: It's lion. What's this? \\
\cline { 2 - 3 } & Back-channel & S2: Sheep. \\
& TA: Um-hum. \\
\hline Corrective Feedback & Recast & \\
\cline { 2 - 3 } & Clarification request & S50: They eat gas. \\
& & TA: Grass. \\
\hline & & TF: Squirrel and deer \\
& & S56: And deer. \\
\cline { 2 - 3 } & Explicit correction & S11: A geese. \\
& & TF: Not a geese. Geese. \\
\cline { 2 - 3 } & Repetition & S12: It orange. \\
& & TD: Orange? \\
\cline { 2 - 3 } &
\end{tabular}




\begin{tabular}{ll}
\hline & S13: Yellow. \\
\hline Elicitation & S42: Cats can climb the trees and \\
& catch mouse. \\
& TF: And can catch... \\
& S42: Catch mice. \\
\hline Metalinguistic Clues & Ss: Geese \\
& TF: A goose and there are some \\
& geese. This is the plural form. \\
& Now, who can read the word? \\
& who can read it? (Pointing at a \\
& student) (Chinese name calling) \\
S5: A goose \\
S15: Dove, dove. \\
TC: Ok. Sit down please.
\end{tabular}

Table 3. Examples of teachers' common speech acts in feedback moves.

\section{Results}

Chinese Primary EFL Teachers' Patterns of Technology Use

Class videos of teachers' technology-enhanced instruction reveal that, although teachers taught the same lesson unit under the same curriculum, there exists a pronounced variation across the eight teachers' levels of engagement in technology-enhanced practices (see Table 4). On average, teachers allocated $54.48 \%$ of their class time for technologyenhanced instruction. For example, in the lesson from Teacher F, 37 minutes and 56 seconds of the class teaching and practices were technology-mediated, accounting for 93.7 $\%$ of the entire class time. By contrast, Teacher E only allocated 4 minutes and 44 seconds of the class for technology-assisted instruction, only $12.44 \%$ of the whole class time.

Table 4

Total Class Time and Technology-Enhanced Instruction Time.

\begin{tabular}{cccc}
\hline Teacher & Total class time & $\begin{array}{c}\text { Technology- } \\
\text { enhanced } \\
\text { instruction time }\end{array}$ & $\%$ \\
\hline TA & $41: 57$ & $31: 06$ & $74.14 \%$ \\
TB & $41: 07$ & $31: 23$ & $76.33 \%$ \\
TC & $34: 58$ & $30: 58$ & $88.56 \%$ \\
TD & $43: 19$ & 18.29 & $42.67 \%$ \\
TE & $38: 03$ & $04: 44$ & $12.44 \%$ \\
TF & $40: 29$ & $37: 56$ & $93.70 \%$ \\
TG & $39: 24$ & $08: 03$ & $20.43 \%$ \\
TH & $35: 12$ & 21.35 & $61.32 \%$ \\
\hline Average & $39: 34$ & $24: 02$ & $54.48 \%$ \\
\hline
\end{tabular}


Despite teachers' various degrees of technology use, the general patterns of technology-assisted practices remain similar. The videos reveal two major modes of technology from the technology-enhanced curriculum—namely, a computer-mediated multimedia courseware program, and the self-made PowerPoint (PPT) slides that teachers composed for presentation (see Table 5). Picture 1 and Picture 2 show an example of the courseware program and a self-made PPT captured from the video clip, respectively. On average, teachers used the courseware program $28.16 \%$ of their class time and PPT for $57.21 \%$ of their class time. For the remaining $14.63 \%$ of their class time, they utilized other text, visual, or audio materials that are not included in the courseware or PPT (See Picture 3). Overall, technology-assisted teaching practices focused on a) listening to dialogs or song from the textbook, b) introducing and reviewing key vocabulary, and c) presenting prompts for listening and speaking practices (see Table 5).

Table 5

Types of Technology Used in Technology-Enhanced Instruction.

\begin{tabular}{|c|c|c|c|c|c|c|c|c|c|}
\hline $\begin{array}{l}\overrightarrow{7} \\
\stackrel{8}{0} \\
\stackrel{2}{9}\end{array}$ & 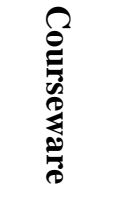 & 竞: & 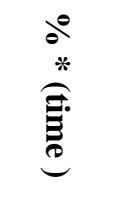 & 吾 & 竞: & 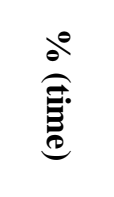 & 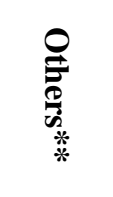 & 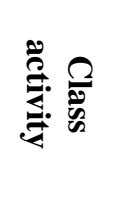 & 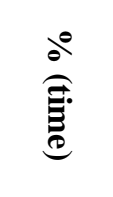 \\
\hline TA & $\begin{array}{c}\text { Text, } \\
\text { Visual, } \\
\text { Audio }\end{array}$ & $\begin{array}{c}\text { Singing } \\
\text { Vocab } \\
\text { Listening } \\
\text { Speaking }\end{array}$ & $\begin{array}{l}20.95 \% \\
(06: 31)\end{array}$ & $\begin{array}{c}\text { Text } \\
\text { Visual }\end{array}$ & $\begin{array}{c}\text { Vocab } \\
\text { Speaking }\end{array}$ & $\begin{array}{l}71.04 \% \\
(24: 35)\end{array}$ & & & \\
\hline TB & $\begin{array}{c}\text { Text, } \\
\text { Audio } \\
\text { Visual }\end{array}$ & $\begin{array}{l}\text { Singing } \\
\text { Vocab }\end{array}$ & $\begin{array}{c}28.84 \% \\
(09: 03)\end{array}$ & $\begin{array}{c}\text { Text } \\
\text { Visual }\end{array}$ & $\begin{array}{c}\text { Vocab } \\
\text { Speaking }\end{array}$ & $\begin{array}{l}71.16 \% \\
(22: 20)\end{array}$ & & & \\
\hline TC & $\begin{array}{c}\text { Text, } \\
\text { Audio, } \\
\text { Visual }\end{array}$ & $\begin{array}{c}\text { Singing } \\
\text { Listening } \\
\text { Vocab } \\
\end{array}$ & $\begin{array}{l}41.77 \% \\
(12: 56)\end{array}$ & & & & $\begin{array}{c}\text { Text, } \\
\text { Visual }\end{array}$ & Vocab & $\begin{array}{c}58.23 \% \\
(18: 02)\end{array}$ \\
\hline TD & $\begin{array}{c}\text { Text, } \\
\text { Audio, } \\
\text { Visual }\end{array}$ & Singing & $\begin{array}{l}13.53 \% \\
(02: 30)\end{array}$ & $\begin{array}{c}\text { Text } \\
\text { Visual }\end{array}$ & $\begin{array}{c}\text { Vocab } \\
\text { Speaking }\end{array}$ & $\begin{array}{l}86.47 \% \\
(15: 59)\end{array}$ & & & \\
\hline $\mathrm{TE}$ & $\begin{array}{c}\text { Text, } \\
\text { Audio, } \\
\text { Visual }\end{array}$ & $\begin{array}{c}\text { Topic } \\
\text { intro } \\
\text { Listening }\end{array}$ & $\begin{array}{c}48.24 \% \\
(02: 17)\end{array}$ & & & & $\begin{array}{c}\text { Text, } \\
\text { Visual, } \\
\text { Audio }\end{array}$ & $\begin{array}{l}\text { Singing } \\
\text { Vocab }\end{array}$ & $\begin{array}{l}51.76 \% \\
(02: 27)\end{array}$ \\
\hline $\mathrm{TF}$ & $\begin{array}{c}\text { Text, } \\
\text { Audio, } \\
\text { Visual }\end{array}$ & Listening & $\begin{array}{l}11.59 \% \\
(04: 24)\end{array}$ & $\begin{array}{c}\text { Text } \\
\text { Visual }\end{array}$ & $\begin{array}{c}\text { Vocab } \\
\text { Topic } \\
\text { intro } \\
\text { Speaking }\end{array}$ & $\begin{array}{l}76.89 \% \\
(29: 10)\end{array}$ & $\begin{array}{c}\text { Text, } \\
\text { Visual, } \\
\text { Audio }\end{array}$ & $\begin{array}{c}\text { Singing } \\
\text { Vocab } \\
\text { Task } \\
\text { intro }\end{array}$ & $\begin{array}{l}11.51 \% \\
(04: 22)\end{array}$ \\
\hline TG & $\begin{array}{c}\text { Text, } \\
\text { Audio, } \\
\text { Visual }\end{array}$ & $\begin{array}{c}\text { Vocab } \\
\text { Speaking } \\
\text { Listening }\end{array}$ & $\begin{array}{l}51.97 \% \\
(04: 11)\end{array}$ & $\begin{array}{c}\text { Text } \\
\text { Visual } \\
\text { Audio } \\
\end{array}$ & $\begin{array}{l}\text { Listening } \\
\text { Vocab }\end{array}$ & $\begin{array}{l}31.88 \% \\
(02: 34)\end{array}$ & Audio & Vocab & $\begin{array}{l}16.15 \% \\
(01: 18)\end{array}$ \\
\hline $\mathrm{TH}$ & $\begin{array}{c}\text { Text, } \\
\text { Audio, } \\
\text { Visual }\end{array}$ & Listening & $\begin{array}{l}19.38 \% \\
(04: 11)\end{array}$ & $\begin{array}{c}\text { Text } \\
\text { Visual } \\
\text { Audio } \\
\end{array}$ & $\begin{array}{c}\text { Vocab } \\
\text { Listening } \\
\text { Speaking }\end{array}$ & $\begin{array}{l}71.27 \% \\
(15: 23)\end{array}$ & $\begin{array}{l}\text { Audio } \\
\text { Visual }\end{array}$ & Singing & $\begin{array}{c}9.34 \% \\
(02: 01)\end{array}$ \\
\hline $\begin{array}{l}\text { Aver } \\
\text { age }\end{array}$ & & & $\begin{array}{l}28.16 \% \\
(06: 46)\end{array}$ & & & $\begin{array}{l}57.21 \% \\
(13: 45)\end{array}$ & & & $\begin{array}{l}14.63 \% \\
(03: 31)\end{array}$ \\
\hline
\end{tabular}

*The percentages here are calculated by Time of each type of technology use / Time of 
total technology use.

**Note: Other types of technology use include video/flash, independent from Courseware or PPT, and the use of Overhead Projector (OHP)

Our analysis demonstrates that teachers employed technology mostly for drill practice or vocabulary learning. Excerpt 1 is an example of this teacher-fronted interaction mediated by technology that frequently occurred in all the teachers' instruction.

Excerpt 1.

(TH: Teacher H; Ss=all students; S21 $=21^{\text {st }}$ student who responded to teacher's elicitation)

1. TH: What's this? (Showing pictures from courseware on the screen)

2. Ss: Sheep

3. TH: What are these?

4. Ss: Goats

5. TH: Where do they live? Okay, S21, please

6. S21: They live on the farm.

7. TH: Ok, very very good. Sit down, please. They live-

8. Ss: On the farm

9. TH: Yes, they live [on the farm] (Showing the phrase on the farm in PPT)
10. Ss: [on the farm]

11. TH: Read after me. On the farm.

12. Ss: On the farm

13. TH: On the farm

14. Ss: On the farm

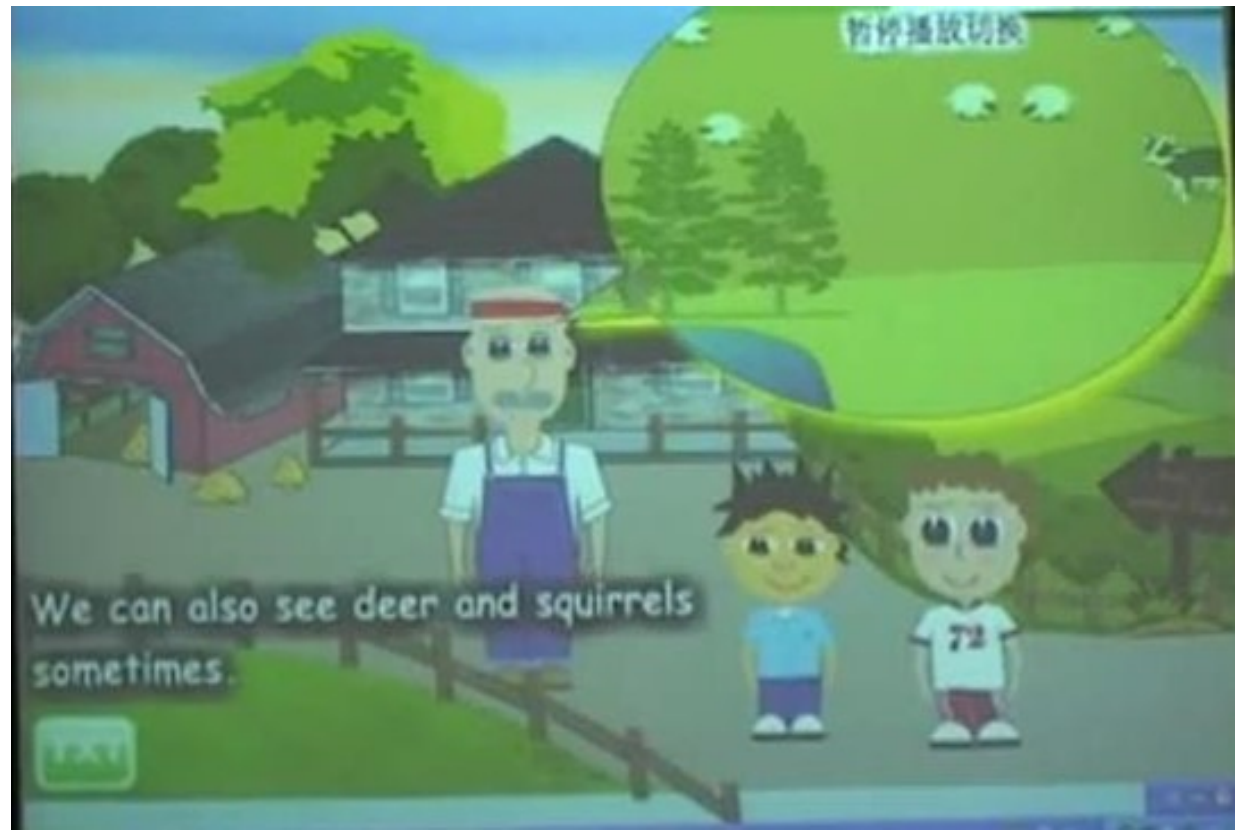

Figure 1. Example of computer-mediated multimedia courseware program during technology-enhanced instruction. 


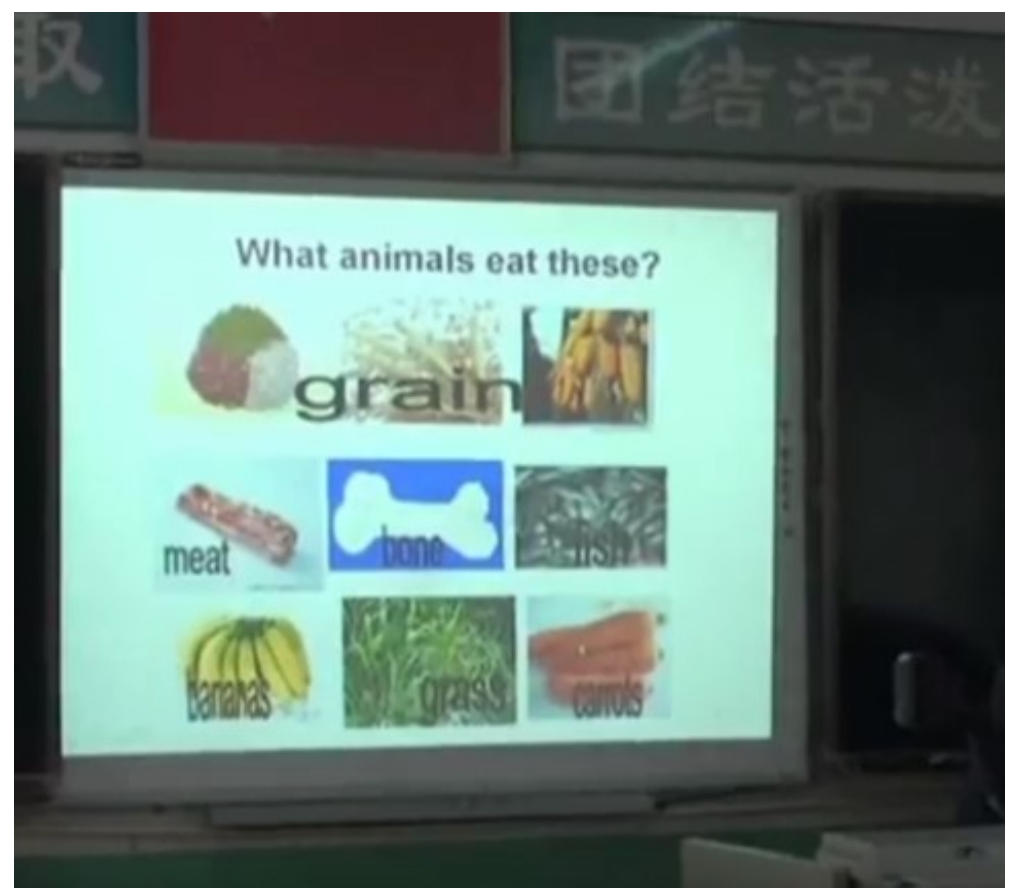

Figure 2. Example of a teacher self-made PowerPoint (PPT) slide during technologyenhanced instruction.

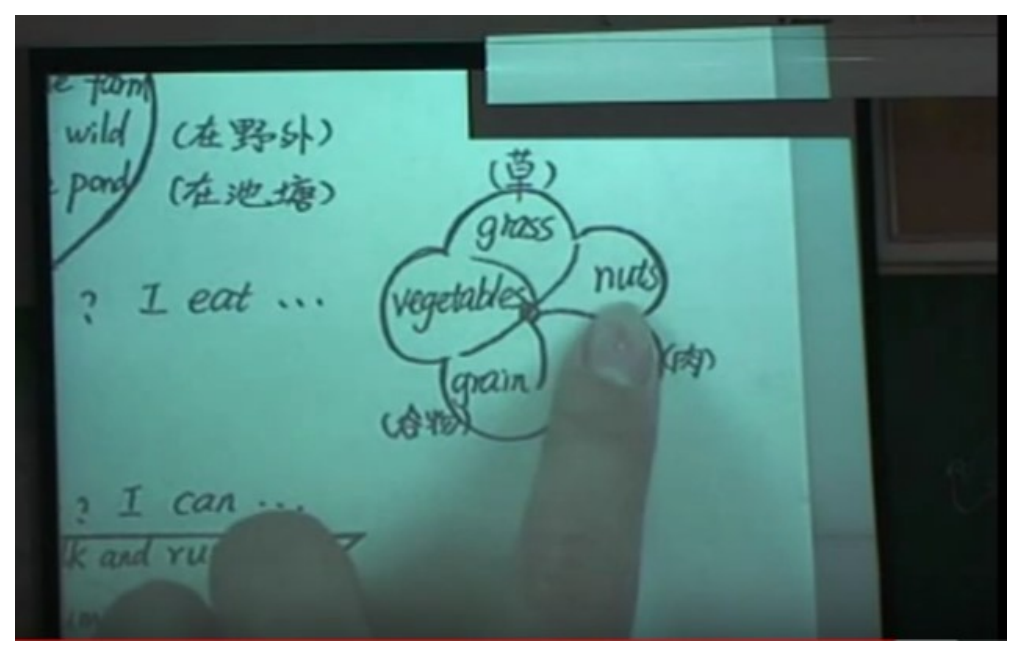

Figure 3. Example of a teacher self-made OHP slide (Overhead Projector) slide during technology-enhanced instruction.

Classroom Interaction Patterns with the Use of Multimedia Technology

Teacher initiation. Our analysis shows that teachers initiated classroom interactions using a variety of technology-assisted resources, including courseware, songs, and video clips, as well as presentation materials on the screen. Table 6 displays the percentage and frequency of teachers' talk for initiation in technology-enhanced instruction. In general, most teachers frequently used questions and directives to begin classroom interaction. On average, $40.54 \%$ of teachers' initiation moves were elicitation, consisting of $34.69 \%$ display questions, $4.36 \%$ referential questions, and $1.49 \%$ of other types of elicitations 
wherein teachers uttered incomplete sentences to elicit responses from the students to fill in the gap (e.g., TC: Who can read the sentence for us? Who can read it? Birds eat...) (see Picture 4). In addition to questions, teachers frequently used imperative sentences such as, "let's listen to the dialogue," or "open your books," to guide class procedures, class activities, or tasks. Approximately one-fourth (25.95\%) of teacher talk for initiation was also model-reading of vocabulary or sentences displayed on the screen or courseware program (see Excerpt 1).

\section{Table 6}

Percentage and Frequency of Speech Acts in Teachers' Initiation Moves in TechnologyEnhanced Instruction.

\begin{tabular}{|c|c|c|c|c|c|c|}
\hline Teacher & & $\begin{array}{c}\text { Elicitation } \\
\% \text { (Frequency) }\end{array}$ & & $\begin{array}{c}\text { Check } \\
\% \\
\text { (Frequency) }\end{array}$ & $\begin{array}{c}\text { Directive to } \\
\text { Action } \\
\% \\
\text { (Frequency) }\end{array}$ & $\begin{array}{l}\text { Model Reading } \\
\text { \% (Frequency) }\end{array}$ \\
\hline & $\begin{array}{l}\text { Display } \\
\text { Question } \\
\% \\
\text { (Frequency) }\end{array}$ & $\begin{array}{l}\text { Referential } \\
\text { Question } \\
\% \\
\text { (Frequency) }\end{array}$ & $\begin{array}{l}\text { Non- } \\
\text { question } \\
\% \\
\text { (Frequency) }\end{array}$ & & & \\
\hline TA & $39.02 \%(64)$ & $6.25 \%(4)$ & $0 \%(0)$ & $14.54 \%$ (24) & $48.48 \%(80)$ & $15.15 \%(25)$ \\
\hline TB & $32.21 \%(48)$ & $4.03 \%(6)$ & $0 \%(0)$ & $8.67 \%(13)$ & $35.33 \%$ (53) & $50.00 \%(75)$ \\
\hline TC & $17.07 \%(14)$ & $8.54 \%(7)$ & $9.76 \%(8)$ & $12.64 \%$ (11) & $36.78 \%(32)$ & $33.33 \%$ (29) \\
\hline TD & $69.72 \%(76)$ & $3.67 \%(4)$ & $0 \%(0)$ & $13.39 \%(15)$ & $32.14 \%(36)$ & $10.71 \%(12)$ \\
\hline $\mathrm{TE}$ & $15.38 \%(4)$ & $0 \%(0)$ & $0 \%(0)$ & $15.38 \%(4)$ & $46.15 \%(12)$ & $38.46 \%(10)$ \\
\hline $\mathrm{TF}$ & $40.28 \%(58)$ & $1.39 \%(2)$ & $1.39 \%(2)$ & $18.18 \%(26)$ & $46.15(66)$ & $18.89 \%$ (27) \\
\hline TG & $33.33 \%$ (13) & $2.56 \%(1)$ & $0 \%(0)$ & $30.77 \%$ (12) & $53.85 \%(21)$ & $2.56 \%(1)$ \\
\hline $\mathrm{TH}$ & $30.53 \%(40)$ & $8.40 \%(11)$ & $0.76 \%(1)$ & $6.67 \%(9)$ & $37.04 \%(50)$ & $38.52 \%(52)$ \\
\hline Average & $34.69 \%$ & $4.36 \%$ & $1.49 \%$ & $15.03 \%$ & $41.99 \%$ & $25.95 \%$ \\
\hline
\end{tabular}

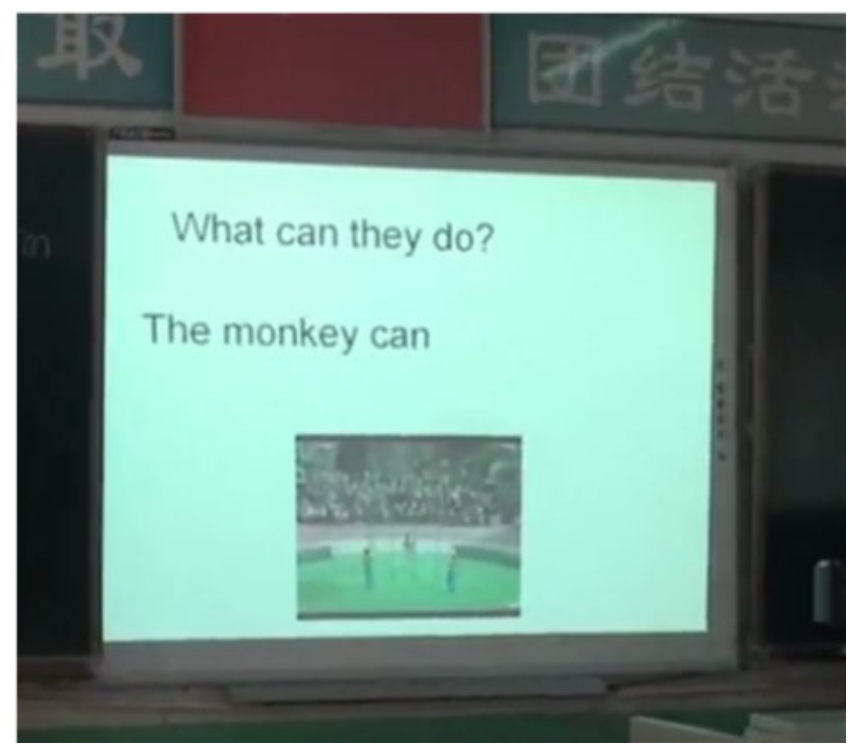

Figure 4. Example of model reading sentences during technology-enhanced instruction. 
Students' responses. As the data demonstrates, students' responses were highly restricted. On average, more than $88 \%$ of students' responses were expected by teachers and students; and only $11.87 \%$ of students' utterances were expanded (see Table 7). Students' responses were often repeated in fixed forms, modeled by the teacher or the technology. For facilitation and clarification purposes, the teacher often read questions verbatim off the screen, requesting several students to repeat a similar or the same answer. As a result, students' spontaneous or expanded responses were rare. Furthermore, and not surprisingly, the most frequent forms of their utterances were answers to closed WHquestions or Y/N questions, or general responses, such as “yes," or "okay” (which accounted for $99.31 \%$ of students' responses as positive responses). Only a few instances of students' self-repair and peer-repair were observed.

In Excerpt 2 from Teacher G's class, Teacher G started with a closed WH-question, "Whose farm is it?" The first student answered in a full sentence, in Chinese. Apart from this one full sentence, students' mostly one-word responses were restricted by the teacher's closed WH-questions (e.g., “what animals are there?”) and Y/N questions. This pattern of students' responses was common across the eight sample lessons.

Table 7

Percentage and frequency of speech acts in student response moves

\begin{tabular}{|c|c|c|c|c|c|c|c|}
\hline Class & Restricted & Expanded & $\begin{array}{l}\text { Positive } \\
\text { Response }\end{array}$ & $\begin{array}{l}\text { Negative } \\
\text { Response }\end{array}$ & $\begin{array}{l}\text { Tempori } \\
\text { zation }\end{array}$ & $\begin{array}{l}\text { Self- } \\
\text { repair }\end{array}$ & $\begin{array}{l}\text { Peer- } \\
\text { repair }\end{array}$ \\
\hline TA & $\begin{array}{l}97.71 \% \\
(171)\end{array}$ & $2.29 \%(4)$ & $100 \%(172)$ & $0 \%(0)$ & $0 \%(0)$ & $\begin{array}{l}11.05 \% \\
(19)\end{array}$ & $\begin{array}{l}1.16 \% \\
(2)\end{array}$ \\
\hline TB & $\begin{array}{l}89.63 \% \\
(147)\end{array}$ & $10.37 \%(17)$ & $98.78 \%$ (162) & $1.22 \%(2)$ & $0 \%(0)$ & $\begin{array}{l}4.27 \% \\
(7)\end{array}$ & $\begin{array}{l}2.44 \% \\
(4)\end{array}$ \\
\hline TC & $\begin{array}{l}95.60 \% \\
(87)\end{array}$ & $4.40 \%(4)$ & $100 \%(91)$ & $0 \%(0)$ & $0 \%(0)$ & $\begin{array}{l}3.30 \% \\
(3)\end{array}$ & $\begin{array}{l}1.10 \% \\
\text { (1) }\end{array}$ \\
\hline TD & $\begin{array}{l}78.57 \% \\
\text { (99) }\end{array}$ & $21.43 \%$ (27) & $99.21 \%(125)$ & $0.79 \%(1)$ & $0 \%(0)$ & $\begin{array}{l}5.56 \% \\
(7)\end{array}$ & $4.76(6)$ \\
\hline TE & $100 \%(30)$ & $0 \%(0)$ & $100 \%(30)$ & $0 \%(0)$ & $0 \%(0)$ & $0 \%(0)$ & $0 \%(0)$ \\
\hline TF & $\begin{array}{l}80.00 \% \\
(132)\end{array}$ & $20.00 \%(33)$ & $98.13 \%(157)$ & $1.88 \%$ (3) & $0 \%(0)$ & $\begin{array}{l}5.00 \% \\
(8)\end{array}$ & $\begin{array}{l}0.63 \% \\
\text { (1) }\end{array}$ \\
\hline TG & $\begin{array}{l}81.82 \% \\
(36)\end{array}$ & $18.18 \%(8)$ & $100 \%(44)$ & $0 \%(0)$ & $0 \%(0)$ & $\begin{array}{l}2.27 \% \\
(1)\end{array}$ & $0 \%(0)$ \\
\hline TH & $\begin{array}{l}81.75 \% \\
(103)\end{array}$ & $18.25 \%(23)$ & $99.21 \%(125)$ & $0.79 \%(1)$ & $0.79 \%(1)$ & $\begin{array}{l}1.59 \% \\
(2)\end{array}$ & $\begin{array}{l}2.38 \% \\
\text { (3) }\end{array}$ \\
\hline Average & $88.14 \%$ & $11.87 \%$ & $99.31 \%$ & $0.59 \%$ & $0.10 \%$ & $4.13 \%$ & $1.56 \%$ \\
\hline
\end{tabular}

Excerpt 2.

(TG=Teacher G; Ss=all students; S10-13=10-13 ${ }^{\text {th }}$ students who responded to teacher's elicitation)

(Courseware-Video clip played)

1. TG: Okay now, here the first question, who can tell me? Whose farm is it? 这是谁 的农场 (Whose farm is it). Okay, you please. (Pointing at a student)

2. S10: 这是Tom他爷爷的农场 (This is Tom's grandpa's farm). 
3. TG: How to say 爷爷(grandfather) Tom's grand-

4. Ss: Grandfather

5. TG: We can also say

6. Ss: Grandpa

7. TG: Okay, very good. grandpa's. Okay. Tom and Mingming are going to visit Tom's grandpa's farm. Okay, very good. Now the second question. After the story, what animals are there, on the farm? 都有什么动物啊,好像大家刚才都听到了, 都什么动物啊 (What animals are there. You all have heard just now. What animals are there) What animals? (pointing at a student)

8. S11: Sheep

9. TG: Sheep. Yes, or no?

10. Ss: Yes.

11. TG: S12.

12. S12: Chickens

13. TG: Chickens. Okay good. Chickens. S13.

14. S13: Doves

15. TG: Doves, yes or no?

16. Ss: Yes.

Teacher feedback. Analysis of teacher feedback indicated that the most frequent feedback types were teachers' acceptance (82\%), followed by corrective feedback (16.54\%) and directives (12.75\%) (see Table 8). A closer investigation of the patterns of teacher feedback revealed that, although the frequencies of teacher-student interaction were high, the three-turn (IRF) sequence often ended either with short comments, such as "very good,” or echoes of students' responses. Excerpt 3 from teacher D illustrates classroom interaction characterized by teacher-led turn completion; accordingly, the length of the three-turn sequence (IRF) remains short. The teacher's uptake of students' responses (as seen in the example of "shark") was rare across all teachers' technology-enhanced instruction.

Table 8

Percentage and Frequency of Teachers' Feedback During Technology-Enhanced Instruction

\begin{tabular}{llll}
\hline Teacher & $\begin{array}{l}\text { Acceptance } \\
\text { \% (frequency) }\end{array}$ & $\begin{array}{l}\text { Corrective Feedback } \\
\text { \% (frequency) }\end{array}$ & $\begin{array}{l}\text { Directive to Action } \\
\text { \% (frequency) }\end{array}$ \\
\hline TA & $70.40 \%(69)$ & $26.53 \%(26)$ & $3.06 \%(3)$ \\
TB & $82.72 \%(67)$ & $20.99 \%(17)$ & $11.11 \%(9)$ \\
TC & $74.51 \%(38)$ & $23.53 \%(12)$ & $27.45 \%(14)$ \\
TD & $84.88 \%(73)$ & $17.44 \%(15)$ & $3.49 \%(3)$ \\
TE & $87.50 \%(7)$ & $12.50 \%(1)$ & $0 \%(0)$ \\
TF & $75.83 \%(91)$ & $18.33 \%(22)$ & $27.50 \%(33)$ \\
TG & $86.21 \%(25)$ & $6.90 \%(2)$ & $17.24 \%(5)$ \\
TH & $93.94 \%(62)$ & $6.06 \%(4)$ & $12.12 \%(8)$ \\
\hline Average & $82.00 \%$ & $16.54 \%$ & $12.75 \%$ \\
\hline
\end{tabular}


Excerpt 3.

(TD=Teacher D; Ss=all students; S44-46: $44^{\text {th }}-46$ th students who responded to teacher's elicitation)

1. TD: Ok, let's practice. 咱练习一下, 关于, about the habitat. 关于栖息地 (Now, let's practice

about the animals' habitats). (Turns off the light, and pictures displayed on the screen) What is this?

2. Ss: Sea.

3. TD: Very good. S43, what's this?

4. S43: Sea.

5. TD: Um, very good. Sea. So, where do they live?

6. S44: Shark.

7. Ss: Shark.

8. TD: Shark. This is a shark. Very good. Where do they live? 它们[在哪生活呀] (Where do they live)?

9. S45:

[In the... ]

10. Ss: In the sea.

11. S46: They live in the sea.

12. TD: Very good, S46. They live in the sea.

With respect to teachers' corrective feedback responding to students' spoken errors (see Table 8), most teachers produced little or no corrective feedback, except in cases of recast. On average, $7.52 \%$ of teachers' error feedback was recast; $2.01 \%$ and $2.20 \%$ consisted of clarification request and explicit correction, respectively. The other three types of corrective feedback - repetition, elicitation, and metalinguistic clues-amounted to below $2 \%$ of teacher feedback. Given that students were expected to produce highly structured responses to the excessive closed questions modeled by technology, it is not surprising that teachers needed to provide frequent corrective feedback. 
Table 9

Percentage and Frequency of Teachers' Corrective Feedback Acts During TechnologyEnhanced Instruction.

\section{Corrective Feedback}

$\%$ (frequency)

\begin{tabular}{|c|c|c|c|c|c|c|}
\hline 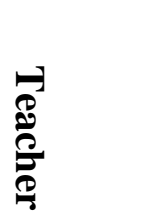 & 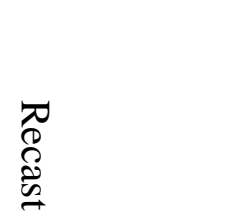 & 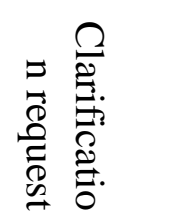 & 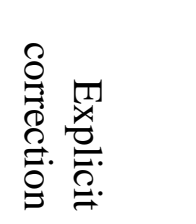 & 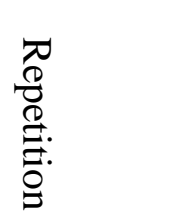 & 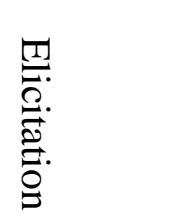 & 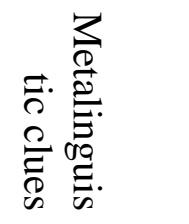 \\
\hline TA & $22.45 \%(22)$ & $1.02 \%(1)$ & $0 \%(0)$ & $0 \%(0)$ & $2.04 \%(2)$ & $0 \%(0)$ \\
\hline TB & $12.35 \%(10)$ & $0 \%(0)$ & $1.23 \%(1)$ & $4.94 \%(4)$ & $1.23 \%(1)$ & $1.23 \%(1)$ \\
\hline TC & $7.84 \%(4)$ & $\begin{array}{l}11.76 \% \\
(6)\end{array}$ & $3.92 \%(2)$ & $0 \%(0)$ & $0 \%(0)$ & $0 \%(0)$ \\
\hline TD & $6.98 \%(6)$ & $0 \%(0)$ & $3.49 \%(3)$ & $3.49 \%(3)$ & $2.33 \%(2)$ & $1.16 \%(1)$ \\
\hline $\mathrm{TE}$ & $0 \%(0)$ & $0 \%(0)$ & $0 \%(0)$ & $0 \%(0)$ & $0 \%(0)$ & $\begin{array}{l}12.50 \% \\
\text { (1) }\end{array}$ \\
\hline $\mathrm{TF}$ & $7.50 \%(9)$ & $\begin{array}{l}3.33 \% \\
(4)\end{array}$ & $2.50 \%(3)$ & $0.83 \%(1)$ & $\begin{array}{l}3.33 \% \\
(4)\end{array}$ & $0.83 \%(1)$ \\
\hline TG & $0 \%(0)$ & $0 \%(0)$ & $3.45 \%(1)$ & $0 \%(0)$ & $3.45 \%(1)$ & $0 \%(0)$ \\
\hline $\mathrm{TH}$ & $3.03 \%(2)$ & $0 \%(0)$ & $3.03 \%(2)$ & $0 \%(0)$ & $0 \%(0)$ & $0 \%(0)$ \\
\hline Average & $7.52 \%$ & $2.01 \%$ & $2.20 \%$ & $1.16 \%$ & $1.55 \%$ & $1.97 \%$ \\
\hline
\end{tabular}

Discussion

In this study, we examined eight primary EFL teachers' technology use and their interactions with students during technology-enhanced instruction. The findings indicate that, although there existed a variance in the time that teachers allocated for technology, most teachers mainly used two modes of technology-multimedia courseware and Power Point (PPT) slides - for introducing key vocabulary, conducting listening practice or drill practice during reading aloud, and presenting information with respect to class activities. Teachers' technology use patterns confirm the existing literature that teachers have the tendency to use technology for teacher-centered purposes, such as teaching preparation or presentation tools (Li \& Ni, 2011a, 2011b; C. H. Xu, 2006; J. Xu, 2010; Zhong \& Shen, 2002). This teacher-fronted use could be due to practical constraints, such as the limited resources for individual students in this suburban/rural district or teachers' lack of knowledge regarding technology integration in the classroom ( $\mathrm{Li} \& \mathrm{Ni}$, 2012; Lam, 2000). In terms of classroom interaction, our conversational analysis of recorded lessons 
reveals that three-turn sequence interactions (IRF) frequently occurred (Y. Lee, 2008; Long \& Sato, 1983; Thornbury, 1996; Walsh, 2002). These interactions were mostly initiated by teachers when using directives to guide students to the next response move or posing prototypical questions relating to the content displayed in teaching materials (such as PPT, video clips, or the courseware program). Among teacher elicitation questions, teachers extensively used closed display questions, using fewer referential questions (closed or open-ended). Although teachers can produce effective interactional exchanges through display questions (Y. Lee, 2008), the teachers in this study frequently used identical display questions and often completed their turns without asking additional questions.

The investigation of student responses revealed that interaction patterns were highly structured across all eight samples, and that the frequency of students' expanded responses was consistently low. In findings similar to previous research, students' responses were restricted by excessive teacher talk time and teachers' control over the content and procedure of the classroom interaction (Cheng, 2009; Walsh, 2002). The extent of teacher control prevented students from producing authentic and pedagogically meaningful interactional exchanges.

The teachers were found to have employed a variety of feedback strategies. The most frequent types of teacher feedback were positive feedback and echo as a way of accepting students' responses. Teacher feedback also included many directives to guide student response moves. These acts of positive evaluation and directives, however, did not always have real pedagogical functions. In keeping with the existing body of research, this study also found that recast was the most prominent type of teachers' corrective feedback (Ahangari \& Amirzadeh, 2011; Kennedy, 2010; Panova \& Lyster, 2002; Sheen, 2004). Nevertheless, most teachers generally produced little corrective feedback (i.e., clarification requests, explicit corrections, repetitions, elicitations, or metalinguistic clues) when technology was introduced. This infrequent use of corrective feedback might be related to highly traditional instructional contexts or the low proficiency levels of primary students who were in the early stages of their English learning (Ahangari \& Amirzadeh, 2011; Sheen, 2004).

Lastly, although teacher-fronted tasks, teacher-led turn completion, and teacher echo have been found to discourage classroom interaction (Walsh, 2002), our analysis of sample lessons revealed that this pattern of teacher talk-in both initiation and feedback moves-led to high frequencies of interactions or exchanges between students and teachers. However, these frequent interactions were often characterized by teacher-led turn completion and weak learner repair (i.e., self or peer repairs). This finding suggests the need for developing a repertoire of teacher talk for dialogic moves in technology-enhanced instruction.

Shifting from this close-up examination of classroom interactions to a wide-angle purview of EFL education in China, it is worth noting that a few studies have identified teachers' persistent use of teacher-centered pedagogical styles as a consequence of urbanrural educational inequality (D. Wang, 2011; J. Wang, 2006). In their early overview of English language teaching in China, Cortazzi and Jin (1996) remarked that significant differences existed in English language teaching developments between cities and rural areas including small towns and the countryside. Clear differences in terms of students' English proficiency, previous English exposure and learning experiences, classroom participation, and language learning strategies have been linked to the urban-rural divide 
in educational resource distribution. Faced with learners with little or no head start in English language learning, teachers in rural regions find their hands tied when experimenting with or conducting student-centered, communicative language instruction under the high-level, fast-paced new curriculum. For instance, in a study on teaching practices in rural classrooms in China, D. Wang (2011) perceived teachers' persistent reluctance to student-centered teaching not as their disagreement with the ideal of the educational reform, but as a strategy for self-protection. Compared with student-centered methods, lecture-style teaching and rote learning are less time-consuming and more predictable-enabling rural teachers of low-performing learners to keep up with the national curriculum. This tension between "the request for decentralized pedagogy and the persistence of a highly centralized curriculum and a fixed schedule" (D. Wang, 2011, p. 157) exacerbates existing educational inequalities already faced by poorly supported rural teachers and their inadequately prepared students. Therefore, before questioning the validity of teachers' pedagogical practices in technology-enhanced classrooms, we need to first pause and consider whether these teachers are sufficiently supported with professional and infrastructural resources and context-appropriate materials, and then critically examine the competing agendas teachers are tackling in their specific teaching contexts.

\section{Conclusions and Implications}

The findings on technology use and the teacher-student interactions facilitated by such technology use suggested that the use of technology in these suburban/rural primary EFL classrooms was, unfortunately, restricting the communicative practices in the classroom. Our analysis revealed that technology was used as an alternative presentation tool to chalkboards and served a range of traditional pedagogical goals in teacher-centered classrooms. The use of technology also limited teacher talk and minimized students' spontaneity and authenticity in the target language output. In this sense, teacher-student interactions resembled those within traditional classrooms operating without technology.

Our findings caution against extensive teacher-controlled technology use in EFL classrooms. While multimedia courseware with native English input may increase the ease of teaching in English for non-native speaking EFL teachers and enable a variety of activities that could not be accomplished in traditional EFL classrooms, its use as a teachercontrolled delivery tool may hinder students' development in communicative competence. Future research should examine the best practices for using technology as a meditational tool for student-centered learning that promotes students' active production of a target language. Thus, this study calls for professional development and further research on ways to help teachers effectively engage in dynamic classroom interactions with the aid of technology.

This technology-assisted, student-centered learning is particularly crucial for rural classrooms like those in our study, where the use of computer and digital technologies has not been routinized in learners' everyday lives and students have limited time to practice English for authentic purposes. Without considering the confluence of both dimensions of technology-assisted EFL teaching, the academic achievement of rural EFL learners will be severely compromised. The incorporation of teacher-controlled technology in EFL teaching practices risks reinforcing teachers as authority figures, thereby decreasing students' opportunities to use language in the classroom, lowering their motivation to learn, and limiting their opportunities to benefit from the affordances that technology brings to 
language learning (including access to more materials, communicative opportunities, and individualized feedback that could lead to increased student motivation). However, as a cautionary note, implementing technology-assisted, student-centered instructional practices in rural school contexts should also consider the reality of the digital divide, which can lead to incompatible if not conflicting learning experiences for learners in school and at home. Therefore, student-centered EFL teaching in technology-assisted rural school contexts requires contextualized pedagogical adjustments that seek to remedy rather than widen the digital gap; that is, to accommodate students' lack of language and technological access. Professional development for rural teachers on how to address these double challenges for their students should be a priority in teacher development in rural schools in China.

The rapid evolution of new technologies in contemporary society will equip EFL teachers with various options for language teaching through "computer-human interaction" and "computer-mediated communication," such as social media, mobile technologies, Web pages, and digital communication software that transcend space and time (Chapelle, 2007; Chun, Smith, \& Kern, 2016; Lotherington \& Jenson, 2011). However, despite these new developments and affordances, our study points to the need to closely examine teacher practices with new technology, including questioning how and for what pedagogical purposes it is being used. Such examination should also be accompanied by an understanding of teachers' enacted beliefs of technology and language learning in their classrooms - hence the need for observing how technologies are actually utilized in the L2 classroom (Chun et al., 2016; Hong, 2010; Lam, 2000).

Finally, the findings of this study suggest that regardless of how technology is used, there is a need for primary teachers to reflect on the objectives of language pedagogy. If the goal of China's vast investment in technology in K-12 education is to transform traditional models of foreign language education-especially in its under-resourced suburban/rural schools-more professional development on how to make technology a student-centered learning tool that enhances student competencies in EFL classrooms is urgently needed.

\section{References}

Ahangari, S., \& Amirzadeh, S. (2011). Exploring the teachers' use of spoken corrective feedback in teaching Iranian EFL learners at different levels of proficiency. Social and Behavioral Sciences, 29, 1859-1868.

Arizavi, S., Kalhor, P. R., Namdari, N., \& Mousavi, S. A. (2015). Classroom interaction and teachers' uptake in response to teachers' referential and display questions in EFL setting. Modern Journal of Language Teaching Methods, 5(4), 538-548.

Chapelle, C. A. (2007). Technology and second language acquisition. Annual Review of Applied Linguistics, 27, 98-114.

Cheng, X. T. (2009). An analysis of English teachers' classroom discourse. Shanghai: Shanghai Foreign Language Education Press.

Chinese Ministry of Education. (2001). 全日制义务教育普通高级中学英语课程标准( 实验稿) [English curriculum standards for full-time compulsory education and senior high schools (trial version)]. Beijing: Beijing Normal University Press.

Chinese Ministry of Education. (2012). 教育信息化十年发展规划[Plan for ICT in Education 2011-2020]. Retrieved from 
http://old.moe.gov.cn/publicfiles/business/htmlfiles/moe/s3342/201203/xxgk_13 3322.html

Chinese Ministry of Education. (2016). 教育信息化”十三五”规划[Educational informatization in the Thirteenth Five-Year Plan]. Retrieved from http://www.ict.edu.cn/laws/new/n20160617_34574.shtml

Chun, D., Smith, B., \& Kern, R. (2016). Technology in language use, language teaching, and language learning. The Modern Language Journal, 100(S1), 64-80.

Cortazzi, M., \& Jin, L. (1996). English teaching and learning in China. Language Teaching, 29, 61-80.

Fan, Y., \& Cheng, Q. (2015). 重庆市城乡学生高考成绩差异的实证分析 (Empirical analysis of urban-rural students' performance gap in college entrance exam in Chongqing). 教育测量与评价 (Educational Measurement and Evaluation), 8(11), 44-50.

Fang, X., \& Warschauer, M. (2004). Technology and curricular reform in China: A case study. TESOL Quarterly, 38(2), 301-323.

Farahian, M., \& Rezaee, M. (2012). A case study of an EFL teacher's type of questions: An investigation into classroom interaction. Procedia - Social and Behavioral Science, 47, 161-167.

Faruji, L. F. (2011). Discourse analysis of questions in teacher talk. Theory and Practice in Language Studies, 1(12), 1820-1826.

Gao, J. (2009). 多媒体环境下英语阅读课深层次拓展的策划 [Strategies to extend communicative output in English reading instruction in a multimedia environment]. 中小学英语教学与研究, 7(231), 39-40.

Hong, K. H. (2010). CALL teacher education as an impetus for L2 teachers in integrating technology. ReCALL, 22(1), 53-69.

Hu, G. (2005). English language education in China Policies, progress, and problems. Language Policy, 4(5), 5-24.

Jung, U. (2005). CALL: Past, present, and future-A bibliometric approach. ReCALL, 17(1), 4-17.

Ke, Z. (2016). 课程改革与农村学生的学业成功机会: 基于A市八年中考数据的分析 [Curriculum reform and rural students' opportunity for academic success: Analysis of eight-year high-school entrance exam data from City A]. 教育研究 [Educational Research], 10, 95-105.

Kennedy, S. (2010). Corrective feedback for learners of varied proficiency levels: A teacher's choices. TESL CANADA Journal, 27(2), 31-50.

Kim, S. (2005). The teacher talk of native English speaker teaching English in a primary school. Primary English Education, 11(2), 233-263.

Lai, F., Zhang, L., Bai, Y., Liu, C., Shi, Y., Chang, F., \& Rozelle, S. (2016). More is not always better: Evidence from a randomised experiment of computer-assisted learning in rural minority schools in Qinghai. Journal of Development Effectiveness, 8(4), 449-472. DOI: 10.1080/19439342.2016.1220412

Lam, W. (2000). L2 literacy and the design of the self: A case study of a teenager writing on the internet. TESOL Quarterly, 34, 457-482.

Lee, J. (2007). Corrective feedback and learner uptake in English immersion classrooms at the primary level in Korea. English Teaching, 62(4), 311-334. 
Lee, Y. (2008). Yes-no questions in the third-turn position: Pedagogical discourse processes. Discourse Processes, 45(3), 237-262.

Lei, X. (2009). Communicative teacher talk in the English classroom. English Language Teaching, 2(1), 75-79.

Leng, T. C. (2005). 英语作文写作e-mail接龙活动初探 [The use of email in high school online English writing instruction]. 中小学英语教学与研究 [Primary and Secondary English Teaching and Research], 2 (176), 42-44.

Li, G. (2015). Low-SES ELLs’ new literacies outside school: Attitudes, access, and agency.

In P. Schmidt \& A. Lazar (Eds.), Reconceptualizing literacy in the new age of multiculturalism and pluralism (2nd ed.) (pp. 255-272). Greenwich, CT: Information Age Publishing.

Li, G., \& Ni, X. (2008). 新信息技术应用与意义构建型教学课程设计：理论和实践 [Information technology integration in meaning-based EFL curriculum design: Theory and practice], 新课程 [New Course], 7, 4-6.

Li, G., \& Ni, X. (2011a). Primary EFL teachers’ technology use in China: Patterns and perceptions. RELC Journal: A Journal of Language Teaching and Research in Southeast Asia, 42(1), 69-85.

Li, G., \& Ni, X. (2011b). Elementary in-service teachers' beliefs and uses of technology in China: A survey study. International Journal of Technology in Teaching and Learning, 6(2), 116-132.

Li, G., \& Ni, X. (2012). Use of technology to support the learning and teaching of English in China. In C. Leung \& J. Yuan (Eds.), Perspectives on teaching and learning English literacy in China (pp. 145-160). New York, NY: Springer.

Li, G., \& Ni, X. (2013). Effects of a technology-enriched, task-based language teaching curriculum on Chinese elementary students' achievement in English as foreign language. International Journal of Computer-Assisted Language Learning \& Teaching (IJCALLT), 3(1), 33-49.

Li, J. (2007). 城乡高中学生的焦虑程度与其英语成绩之间的关系 [The relationship between rural and urban students' anxiety level and their performance in English tests]. 外语教学与研究 [Foreign Language Teaching and Research], 45, 69-71.

Li, L., \& Walsh, S. (2010). Technology update in Chinese EFL classes. Language Teaching Research, 15(1), 99-125.

Lin, J. (2004). 基础教育课程改革与农村教师教育[Basic education curriculum reform and rural teacher development]. Education Exploration, 12, 114-115.

Liu, J., \& Le, T. (2012). A case study on college English classroom discourse. International Journal of Innovative Interdisciplinary Research, 2, 1-10.

Long, M. H., \& Sato, C. J. (1983). Classroom foreigner talk discourse: Forms and functions of teachers’ questions. In H. W. Seliger \& M. H. Long (Eds.), Classroom oriented research in second language acquisition (pp. 268-285). Rowley, MA: Newbury House.

Lotherington, H., \& Jenson, J. (2011). Teaching multimodal and digital literacy in L2 settings: New literacies, new basics, new pedagogies. Annual Review of Applied Linguistics, 31, 226-246.

Lyster, R., \& Ranta, L. (1997). Corrective feedback and learner uptake: Negotiation of form in communicative classrooms. Studies in Second Language Acquisition, 19, 
37-66.

Markee, N. P. (2000). Conversation Analysis. Lawrence Erlbaum, Mahwah, NJ.

Marton, A. M. (2006). The cultural politics of curricular reform in China: A case study of geographical education in Shanghai. Journal of Contemporary China, 15(47), 233-254.

McCarthy, M. (1991). Discourse analysis for language teachers. Cambridge: Cambridge University Press.

Mehan, H. (1979). Learning lesson: Social organization in the classroom. Cambridge, MA: Harvard University Press.

Mo, D. (2015). The Impact of Government Upscaling Efforts on the Effectiveness of Computer Assisted Learning Programs in Rural China (Working Paper). Stanford, CA: REAP, Stanford University.

Mo, D., Swinnen, J., Zhang, L., Yi, H., Qu, Q., Boswell, M., \& Rozelle, S. (2013). Can one laptop per child reduce the digital divide and educational gap? Evidence from randomised experiment in migrant schools in Beijing. World Development, 46, 14-29. doi:10.1016/j.worlddev.2012.12.019.

Mo, D., Zhang, L., Luo, R., Qu, Q., Huang, W., Wang, J., Qiao, Y., Boswell, M., \& Rozelle, S. (2014). Integrating computer-assisted learning into a regular curriculum: Evidence from a randomised experiment in rural schools in Shaanxi. Journal of Development Effectiveness, 6(3), 300-323. doi:10.1080/19439342.2014.911770.

Panova, I., \& Lyster, R. (2002). Patterns of corrective feedback and uptake in an adult ESL classroom. TESOL Quarterly, 36, 573-595.

Qashoa, S. H. (2013). Effects of teacher question types and syntactic structures on EFL classroom interaction. The International Journal of Social Sciences, 7(1), 52-62.

Qian, X. L., Tian, G., \& Wang, Q. (2009). Codeswitching in the primary EFL classroom in China: Two case studies. System, 37, 719-730.

Qian, X. L., \& Smyth, R. (2008). Measuring regional inequality of education in China: Widening cost-inland gap or widening rural-urban gap? Journal of International Development, 20, 132-144.

Rashidi, N., \& Rafieerad, M. (2010). Analyzing patterns of classroom interaction in EFL classrooms in Iran. The Journal of Asia TEFL, 7(3), 93-120.

Rural Education Action Program. (2018). Computers as tutors: Leveraging PCs to advance learning in China's rural schools. Retrieved from https://reap.fsi.stanford.edu/sites/default/files/REAP116-EN.pdf

Rong, X. L., \& Shi, T. (2001). Inequality in Chinese education. Journal of Contemporary China, 10(26), 107-124.

Sacks, H. (1992). Lectures on conversation. Oxford, UK: Blackwell.

Sheen, Y. (2004). Corrective feedback and learner uptake in communicative classrooms across instructional settings. Language Teaching Research 8(3), 263-300.

Sinclair, J., \& Coulthard, R. M. (1975). Toward an analysis of discourse. Oxford: Oxford University Press.

Sinclair, J., \& Coulthard, R. M. (1992). Towards an analysis of discourse. In R. M. Coulthard (Ed.), Advances in spoken discourse analysis (pp. 1-34). London: Routledge. 
Song, J., Liang, G., Liu, G., Walls, R., Li, G., Wang, Z., \& Yin, H. (2005). Are teachers in China ready to teach in the $21^{\text {st }}$ century? Journal of Technology and Teacher Education, 13(2), 197-209.

Su, X. M., \& Jing, P. L. (2007). 多媒体网络环境下的小学英语教学评价 [Primary English assessment in multimedia Internet environment]. 中小学英语教学与研 究, 2(201), 40-42.

Ten Have, P. (2007). Doing conversation analysis. Thousand Oaks, CA: Sage.

Thornbury, S. (1996). Teachers research teacher talk. ELT Journal, 50(4), 279-289.

Tsui, A. B. (1985). Analyzing input and interaction in second language classrooms. RELC Journal, 16(1), 8-32.

Tsui, A. B. (1994). English conversation. Oxford, UK: Oxford University Press.

Tsui, A. B. (2001). Classroom interaction. In R. Carter and D. Nunan (Eds.), The Cambridge guide to teaching English to speakers of other languages (pp. 120125). Cambridge: Cambridge University Press.

Verplaetse, L. S. (1995). Discourse modifications in teacher interactions with limited English proficient students in content classrooms (Unpublished doctoral dissertation). Boston University, Boston, MA, USA.

Verplaetse, L. S. (2000). Mr. Wonderful: Portrait of a dialogic teacher. In J. K. Hall \& L. S. Verplaetse (Eds.), Second and foreign language learning through classroom interactions (pp. 221-242). Mahwah, NJ: Lawrence Erlbaum.

Walsh, S. (2002). Construction or obstruction: Teacher talk and learner involvement in the EFL classroom. Language Teaching Research, 6(1), 3-23.

Wang, D. (2011). The dilemma of time: Student-centered teaching in the rural classroom in China. Teaching and Teacher Education, 27, 157-164.

Wang, J. (2006). Difficulties and countermeasures in the implementation of qualityoriented education in rural primary and secondary schools. Jiaoyu Yanjiu (Educational Research), 11, 41-46.

Wu, K. Y. (1993). Classroom interaction and teacher questions revisited. RELC Journal, 24, 49-68.

Xu, C. H. (2006). 多媒体技术在中学英语教学中的应用及误区 [The use and misuse of multimedia technology in middle school English teaching]. 中小学英语教学与 研究, 1 (188), 17-20.

$\mathrm{Xu}, \mathrm{J}$. (2010). On the problems and strategies of multimedia technology in English teaching. Journal of Language Teaching and Research, 1, 215-218.

Yang, C. R. (2007). 多媒体营造出精彩的小学英语课堂 [Use of multimedia technology to create an exciting primary English class]. 中小学英语教学与研究, Special Issue, 53-59.

Yang, Y. (2008). Corrective feedback and Chinese learners' acquisition of English past tense. (Unpublished doctoral dissertation). McGill University, Montreal, QC, Canada.

Zhao, B. (2009). Corrective feedback and learner uptake in primary school EFL classrooms in China. The Journal of Asia TEFL, 6(3), 45-72.

Zhao, Y. (2003). Recent development in technology and language: A literature review and meta-analysis. CALICO Journal, 21, 7-27. 
Zhang, H. L. (2009). 自制课件在词汇教学中的应用 [Use of self-made courseware in English vocabulary instruction]. 中小学英语教学与研究, 11 (236), 18-24.

Zhang, G., \& Zhao, Y. (2014). Achievement gap in China. In J. V. Clark (Ed.), Closing the achievement gap from an international perspective: Transforming STEM for effective education (pp. 217-228). Dordrecht, Netherlands: Springer.

Zhong, Y. X., \& Shen, H. Z. (2002). Where is the technology-induced pedagogy? Snapshots from two multimedia EFL classrooms. British Journal of Educational Technology, 33 (1), 39-52. 